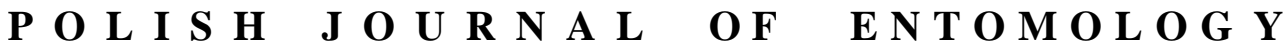

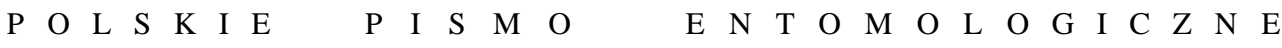

VOL. 84: 33-47

Lublin

30 April 2015

DOI: $10.1515 /$ pjen-2015-0004

\section{Has Aeshna viridis Eversmann, 1836 (Odonata: Aeshnidae) really disappeared from southern Poland (East-Central Europe)?}

\author{
PAWEŁ BUCZYŃSKI ${ }^{1}$, MACIEJ GÓRKA ${ }^{2}$, EdYTA BUCZYŃSKA ${ }^{3}$ \\ ${ }^{1}$ Maria Curie-Skłodowska University in Lublin, Department of Zoology, Akademicka 19, \\ 20-033 Lublin, Poland, e-mail: pawbucz@gmail.com \\ ${ }^{2}$ Infinity Macro - Dragonfly Photography and Conservation, Belwederczyków 21/2, \\ 51-688 Wrocław, Poland, e-mail: macgorka@infinitymacro.com \\ ${ }^{3}$ University of Life Sciences in Lublin, Department of Zoology, Animal Ecology and \\ Wildlife Management, Akademicka 13, 20-033 Lublin, Poland, \\ e-mail: edyta.buczynska@gmail.com
}

\begin{abstract}
Aeshna viridis ran through southern Poland. However, no records of this species from this area have been reported since then. The species is therefore considered as having retreated northwards. The present research disclosed three new sites of $A$. viridis on the edge of or just beyond its historical distribution area: one in south-western Poland (Trestno: $51^{\circ} 04^{\prime} \mathrm{N}, 1^{\circ} 08^{\prime} \mathrm{E}$ ) and two in the south-east of the country (Krasiczyn: $49^{\circ} 46^{\prime} \mathrm{N}, 22^{\circ} 38^{\prime} \mathrm{E}$, Bolestraszyce: $49^{\circ} 49^{\prime} \mathrm{N}, 22^{\circ} 51^{\prime} \mathrm{E}$ ). All the sites were anthropogenic. This demonstrates the survival of a number of populations and the formation of new ones in water bodies formed de novo or to which Stratiotes aloides was introduced artificially. This suggests that the conservation of $A$. viridis is possible in this region.
\end{abstract}

KEY WORDS: Odonata, Aeshna viridis, Poland, distribution, decline, anthropogenic habitats, protection.

\section{INTRODUCTION}

Aeshna viridis EVERSMANN, 1836 is a Siberian zoogeographical element in the European fauna. Its current distribution is described as Palaearctic (BERNARD et al. 2009). It occurs from Siberia to the Netherlands (DIJKSTRA \& LEWINGTON 2014). The boundary of its distribution area in East-Central Europe runs, inter alia, through Poland. Historically, it ran 
through the southern part of the country, but nowadays A. viridis occurs mainly in northern Poland (BERNARD et al. 2009). The regress of this species is even more noticeable in Ukraine (GORB et al. 2000), whereas to the west of Poland A. viridis has already been designated "critically endangered" (OTT \& PIPER 1997) or at best "vulnerable" (TERMAAT \& KALKMAN 2012). For these reasons, all data on its occurrence along the southern border of its distribution area is invaluable. This is all the more significant because A. viridis is mentioned in two important European Legislation Acts. One is the Bern Convention on the Conservation of European Wildlife and Natural Habitats from 1979, the other is the Council Directive 92/43/EEC on the conservation of natural habitats and of wild fauna and flora. In accordance with these acts, A. viridis is protected by law throughout the European Union, including Poland. In this context, therefore, all fresh faunistic data on this species is invaluable for its potential conservation and protection.

We searched for sites of A. viridis on the edge of its distribution area in southern Poland. The aim of the study was to test the assumption that some previously unknown or historical populations of A. viridis, occurring in areas not explored for many years, could have survived there.

\section{MATERIAL AND METHODS}

The fieldwork in south-western Poland was carried out between 2011 and 2014 in the Silesian Lowland, together with the Trzebnica Upland and the Milicz-Głogów Depression in the north and the Sudetic Foreland as far as the Central Sudetes in the south. The largest concentration of explored sites was in the Wrocław Plain mesoregion and the Wrockaw Proglacial Valley (KONDRACKI 2000). The sites were selected for the presence of Stratiotes aloides LinNAEUS, 1753. Site research was based on Polish and German historical information, contemporary literature and Internet sources (ŚwIERKOSZ et al. 2012a, 2012b, GN 2014, SZTWIERTNIA 2014), data provided by botanists from the University of Wrocław and the Wrocław University of Environmental and Life Sciences, data obtained from the analysis of maps and satellite images from Google Maps and Geoportal (geoportal.gov.pl), as well as our own data from previous studies of other Odonata species. Many former sites of $S$. aloides have vanished as a result of overgrowth or drying out. Nevertheless, the species was found at three sites. Dragonfly imagines were observed and exuviae were looked for at all these sites. The data set was derived from 75 sites.

The fieldwork in southern and south-eastern Poland was carried out in 2006-2009, 2011 and 2014 in the following areas: (1) from Goczałkowice to Rzeszów, including the Western Beskid Foothills and the western and central parts of the Central Beskid Foothills together with some adjacent areas; (2) the vicinities of Łańcut and Przemyśl (the Sandomierz Basin); 
(3) selected sites at Krasiczyn (eastern edge of the Central Beskid Foothills); (4) the vicinities of Lesko, Solina and Baligród (Forest Beskid Mountains) (KONDRACKI 2000). Records of imagines usually contained the number of individuals, and details regarding metamorphosis and reproductive behaviour. Exuviae were collected sporadically from shore vegetation, and larvae were caught with a hydrobiological sampler. The data was obtained from 170 sites.

On the basis of the material, the identified species were described as: 1) autochthonous (when larvae were caught, exuviae collected, metamorphosis or numerous reproductive activities observed); 2) probably autochthonous (when few reproductive activities were recorded or numerous populations were sighted in an environment appropriate to the species); 3) recorded species (in all other cases).

The surface areas of the water bodies were measured with tools available on the Geoportal website (geoportal.gov.pl), and altitudes were specified according to Google Earth.

\section{RESULTS}

Aeshna viridis was found at three sites: one in the Silesian Lowland, one in the Central Beskid Foothills and one in the Sandomierz Basin (Fig. 1). The results are discussed below. To indicate accompanying species, two asterisks $(* *)$ were used for autochthonous species and one $(*)$ for probably autochthonous.

\section{Trestno ad Wroclaw $\left(51^{\circ} 04\right.$ '58” $\mathrm{N}, 1^{\circ} 08^{\prime} 25^{\prime}$ 'E, UTM: XS46, $180 \mathrm{~m}$ amsl), former clay excavations}

The Trestno site, a complex of overgrowing clay excavations, is situated in the Wrocław Proglacial Valley mesoregion, in the direct vicinity of the River Oder, within the Blizanowice-Trestno floodplain. Biogeographically the site belongs to NATURA 2000, PLH020017 - Grądy in the Valley of the River Oder - an area of extensively used meadows and forests (mainly alluvial alder-ash and oak-hornbeam forests), with numerous canals, streams, oxbow lakes overgrown with aquatic and marsh vegetation, drainage ditches, backwaters and polders. Stratiotes aloides occurred in two water bodies at this site.

Water body no. 1 (Fig. 2), the largest one, approx. 0.40 ha in area, situated $180 \mathrm{~m}$ southwest of the Nadodrzańska Street, partly covered with beds of Typha angustifolia LiNNAEUS, 1753, contains the highest accumulation of Stratiotes aloides, which occupies an area of ca 0.16 ha. To the south-west, this water body is surrounded by Alnus glutinosa GAERTNER, 1791 and Salix fragilis LinNaEUS, 1753. The shore vegetation consists of Carex pseudocyperus LINNAEUS, 1753, Phalaris arundinacea LinNAEUS, 1753, Tanacetum 
vulgare LINNAEUS, 1753, Erigeron canadensis LINNAEUS, 1753, Cirsium vulgare LINNAEUS, 1753, Bidens frondosa LINNAEUS, 1753, Rosa canina LiNNAEUS, 1753 and Salix fragilis LINNAEUS, 1753.

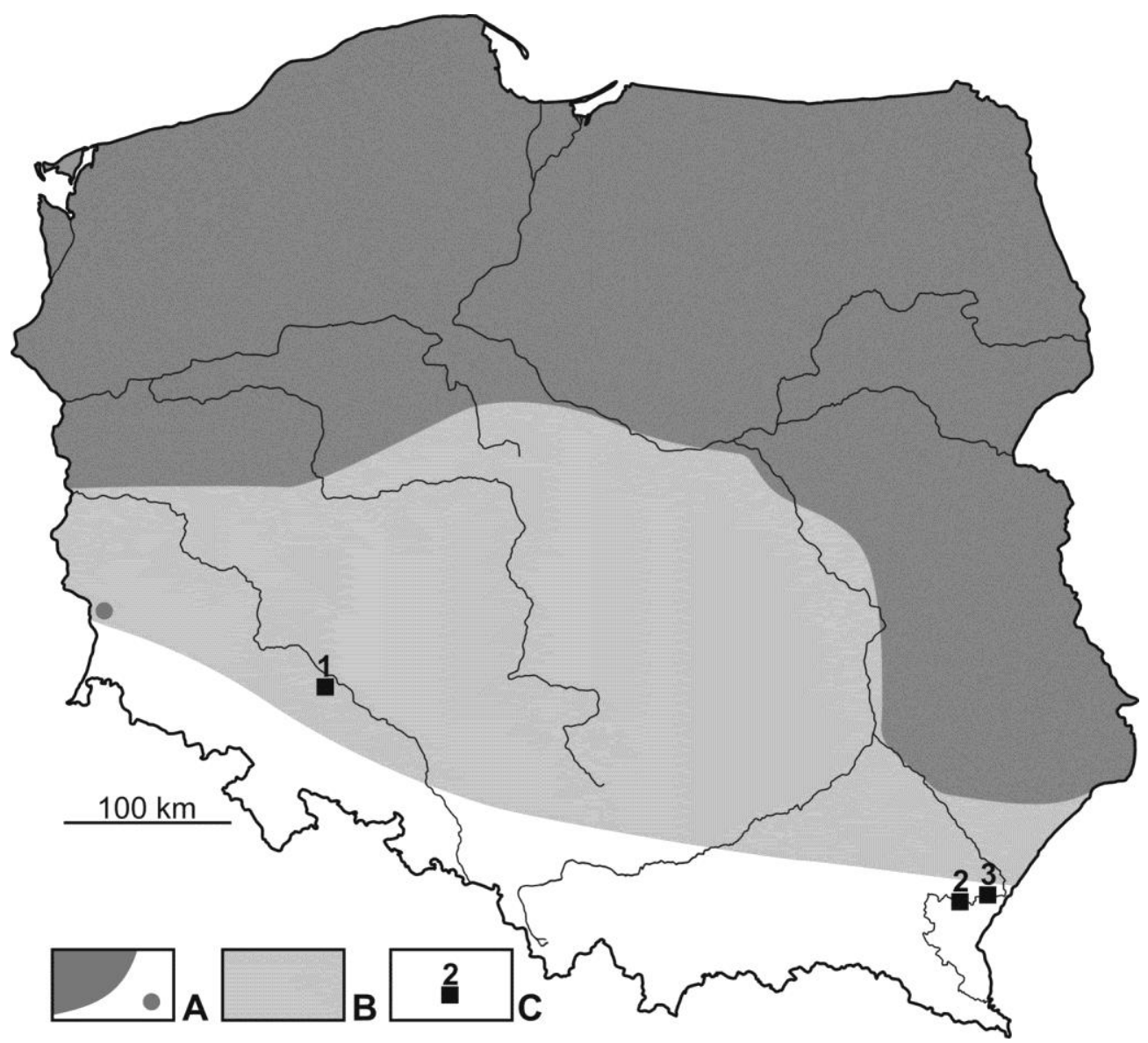

Fig. 1. Distribution area of Aeshna viridis in Poland (BERNARD et al. 2009) and new records of the species. A - current extent, B - probable historical extent, $\mathrm{C}$ - new records (numbering as in the text).

Water body no. 2 (ca $0.03 \mathrm{ha}$ ), situated $50 \mathrm{~m}$ from the floodbank, is surrounded by Typha angustifolia and entirely overgrown with Stratiotes aloides. 


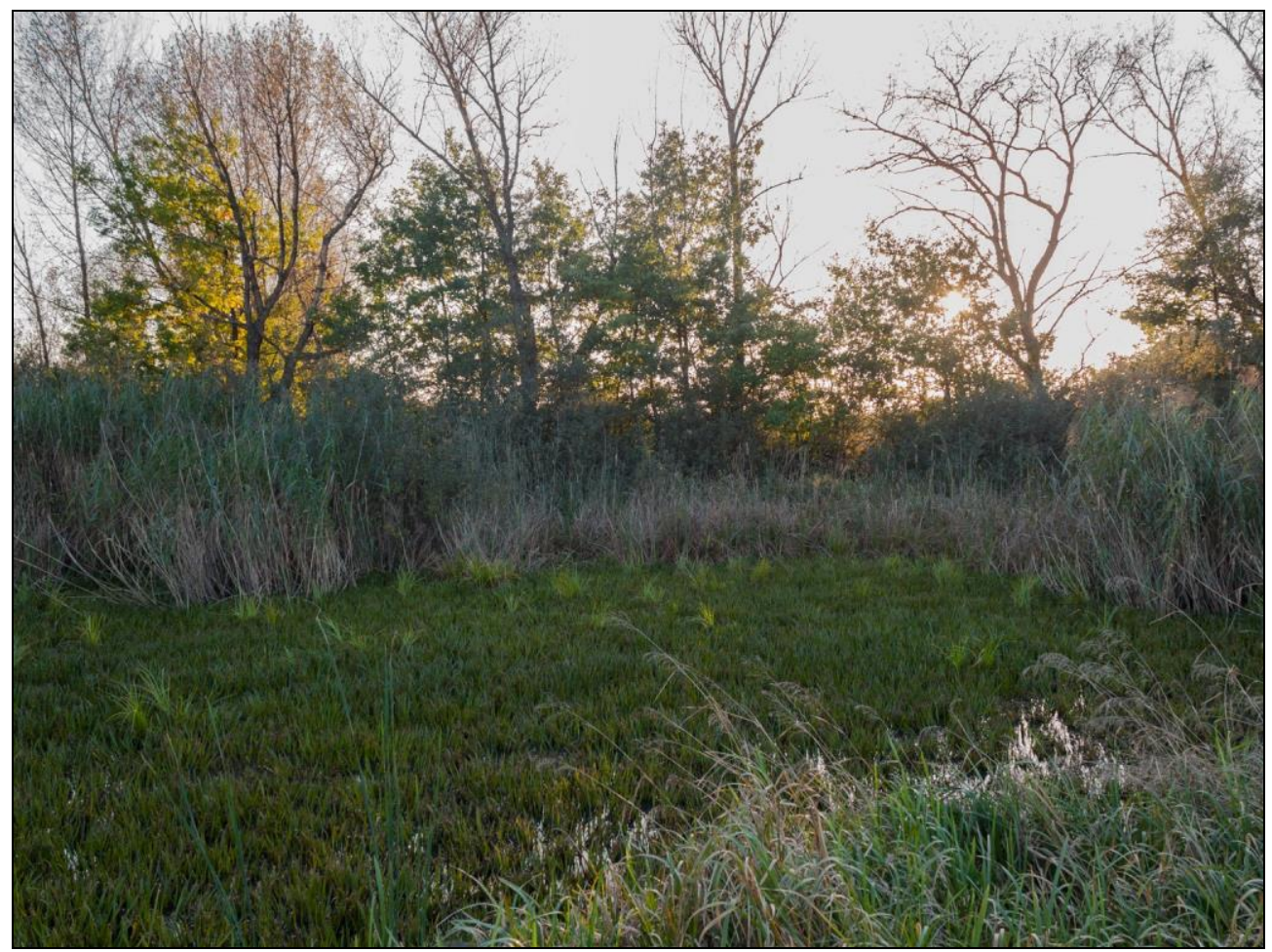

Fig. 2. Trestno, water body no. 1.

Water body no. 3 (0.065 ha), without S. aloides, situated in the neighbourhood of farmland and separated from it by just a narrow strip of shrubs, is an astatic water body, the water level of which depends on the amount of rainfall; fragments of alluvial plant communities are present. To the south this water body is surrounded by a hedge of Salix cinerea LINNAEUS, 1753 and S. fragilis. In this highly diverse, species-rich vegetation the dominants are Eleocharis acicularis (LINNAEUS, 1753) ROEMER et SCHULTES, 1817, Carex pseudocyperus, Glyceria maxima (HARTMAN, 1820) HOLMBERG, 1919, Alopecurus aequalis SOBOLEWSKI, 1799, Sparganium erectum LINNAEUS, 1753, Ranunculus flammula LINNAEUS, 1753, Equisetum fluviatile LINNAEUS, 1753, Schoenoplectus lacustris (LinNAEUS, 1753) PALLA, 1888 and the omnipresent Typha angustifolia.

Records of $A$. viridis:

- Water body no. 1: 17-08-2012, 30-07-2014 and 02-08-2014, each time 1q during oviposition on Stratiotes aloides. On 02-08-2014, 4 territorial $\widehat{\delta} \widehat{\sigma}$ were observed and one exuvium on S. aloides photographed (Fig. 3); 


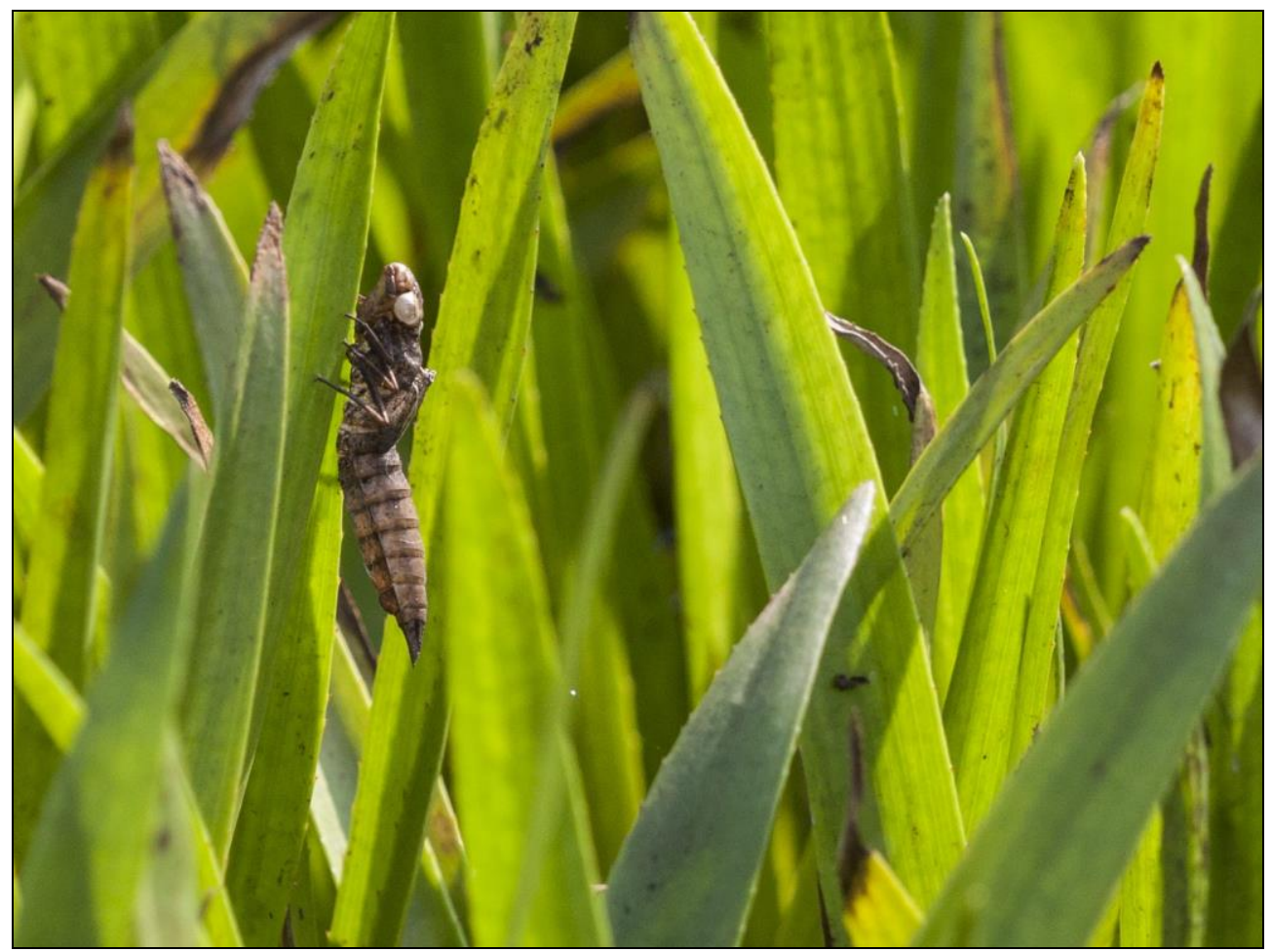

Fig. 3. Trestno, exuvium of Aeshna viridis on Stratiotes aloides - water body no. 1.

- Water body no. 3: 09-07-2013, 10 resting in the nearby wheat field; 23-07-2013, 10 in the wheat field; 30-07-2014, numerous $\widehat{\partial} \delta$ and $q$ 우 after sunset, hunting over the water body together with several $\hat{\partial} \hat{O}$ Aeshna affinis VANDER LINDEN, 1820 and 19 A. grandis (LINNAEUS, 1758); 02-08-2014, numerous $\widehat{\delta} \delta^{\lambda}$ and $\phi+{ }^{\circ}$ hunting at dusk; 03-08-2014, $10^{-1}$ resting in the nearby shrubs (Fig. 4).

Except for a single examination, no follow-up observation was carried out in water body no. 2; accessibility was very difficult owing to the surrounding dense undergrowth and muddy bottom. Nevertheless, the presence of A. viridis seems to be obvious there.

Other Odonata species recorded during the research at this site (collectively): Lestes sponsa (HANSEMANn, 1823), Sympecma fusca (VANDER LINDEN, 1820), Platycnemis pennipes (PALLAS, 1771), Coenagrion puella (LiNNAEUS, 1758), C. pulchellum (VANDER LINDEN, 1825), Brachytron pratense (O.F. MÜLLER, 1764), Aeshna affinis, A. cyanea (O.F. MÜlLER, 1764), A. grandis, A. mixta LATREILLE, 1805**, Anax imperator LEACH, 1815, Gomphus flavipes (CHARPENTIER, 1825), G. vulgatissimus (LINNAEUS, 1758), Libellula quadrimaculata LiNNAEUS, 1758, Orthetrum brunneum (FONSCOLOMBE, 1837), 
O. cancellatum (LinNAEUS, 1758), Sympetrum danae (SULZER, 1776)* and S. sanguineum (O.F. MÜLLER, 1764).

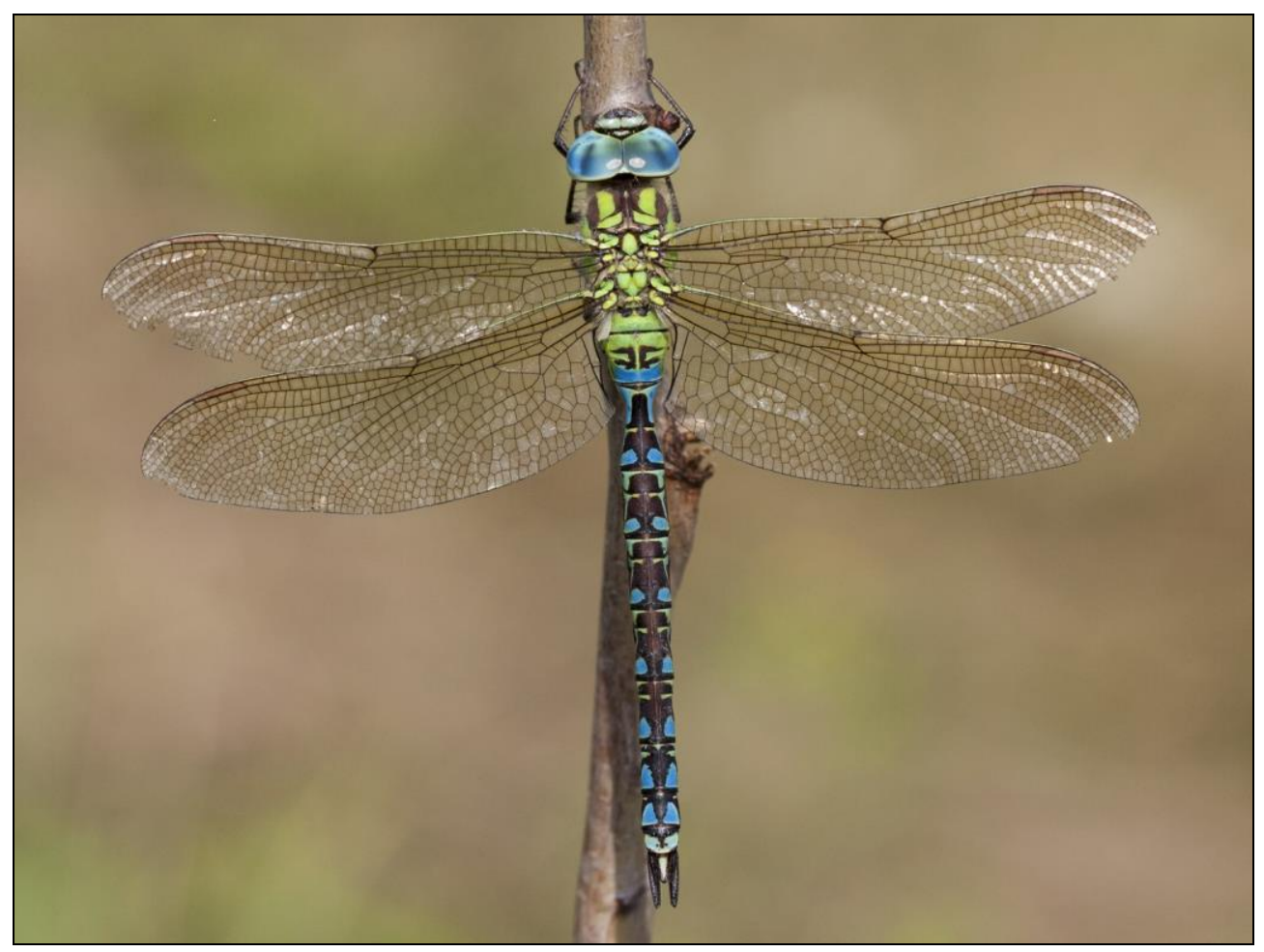

Fig. 4. Trestno, Aeshna viridis - ô resting close to water body no. 3 .

2. Krasiczyn $\left(49^{\circ} 46^{\prime} 27^{\prime} \mathrm{N}, 2^{\circ} 38^{\prime} \mathrm{E56}\right.$ ", FA11, $216 \mathrm{~m}$ amsl), pond in the park near the Krasicki Castle

The Krasicki Castle is situated on the right-bank of the San valley. In the nearby park there are two ponds: one is a pool surrounded by a concrete embankment 0.34 ha in area, only periodically filled with water but without any typical aquatic vegetation (the so-called lower pond); the other pond (the upper pond) (Fig. 5) is a permanent one 1.4 ha in area, eutrophic, with turbid green water. The shores are covered with a dense bed of tall reeds dominated by Phragmites australis (CAVANILlES, 1799) TRINIUS ex STEUdEL, 1840. Locally, there are also small patches of Nymphaea alba LINNAEUS, 1753. 


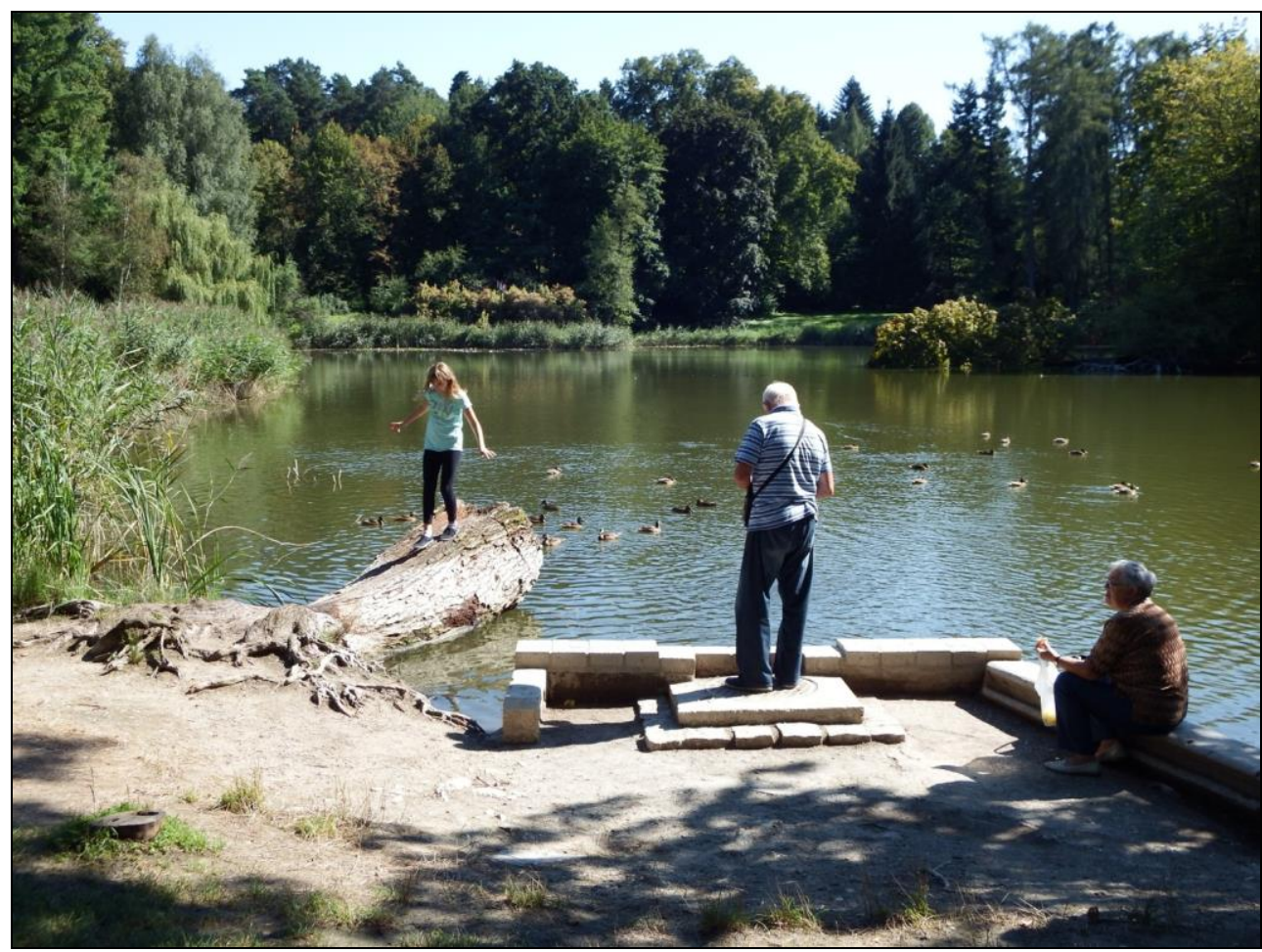

Fig. 5. Krasiczyn, park complex near the castle, the upper pond.

Records of A. viridis: the upper pond: 24 VII 2011, 1 exuvium on an old willow (Salix sp.), by the shore.

Other Odonata species (collectively): Platycnemis pennipes, Ischnura elegans (VANDER LINDEN, 1820)**, Enallagma cyathigerum**, Coenagrion puella**, Aeshna grandis*, Libellula depressa, Orthetrum cancellatum**, Sympetrum sanguineum**, S. vulgatum.

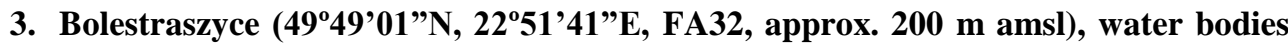
in the Arboretum and the Physiography Department at Bolestraszyce

The arboretum is situated on the left side of the San valley. There are three water bodies, known as the upper ( 0.1 ha), middle ( 0.42 ha) and lower $(0.35$ ha) ponds. They are almost certainly artificial, situated as they are beyond the belt of oxbow lakes on the River San; in the first half of the $19^{\text {th }}$ century there were no water bodies here (HÜBER 1824). Despite lying among trees and shrubs, all three ponds receive adequate insolation. 
The upper pond represents the naturally restored ecosystem of a strongly silted up, swampy eutrophic water body with the water surface completely covered by a pleustonic community with dominant Lemna minor LINNAEUS, 1753. The middle and lower ponds are deeper, with an open water surface. Both contain abundant cultivated vegetation, mainly bulrushes and nymphaeids, with numerous wild and cultivar varieties of native and exotic species. In the lower pond Hippuris vulgaris LINNAEUS, 1753 and Salvinia natans (LinNAEUS, 1753) ALLIONI, 1785 are also abundant. All three ponds contain Stratiotes aloides: it forms isolated patches with a total area of 0.005-0.01 ha (Fig. 6).

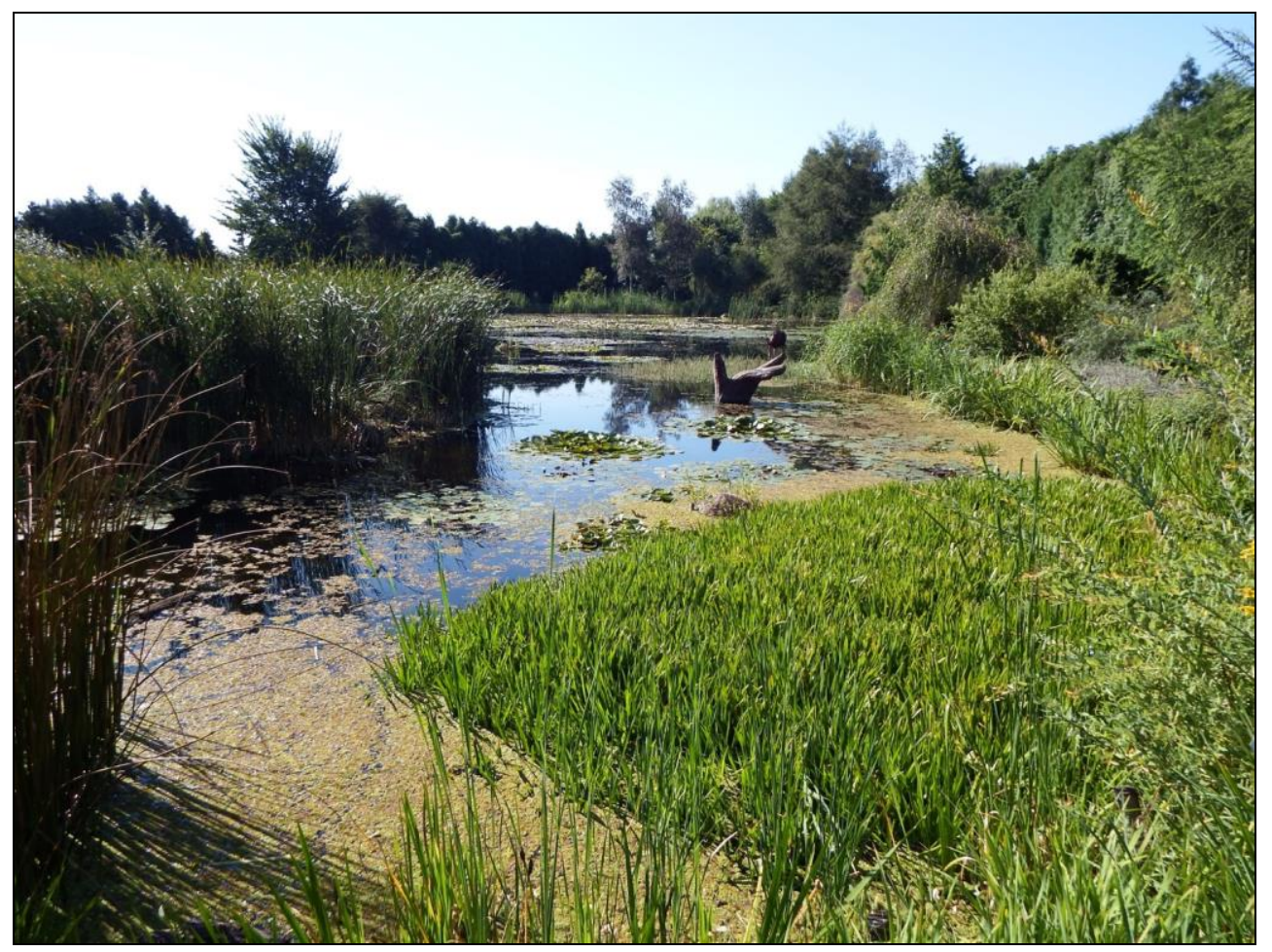

Fig. 6. Bolestraszyce, Arboretum, the lower pond.

Records of A. viridis:

- middle pond: 23-08-2014, 1 territorial $\widehat{\jmath} ; 29-08-2014,1 \delta$ hunting over the paths near the pond;

- lower pond: 23-08-2014, 1-2 territorial $\widehat{\partial} \widehat{\partial}$ and 19 flying low along the shore (probably looking for an oviposition site); 2014-08-29, 1 territorial $\hat{\sigma}$. 
Other Odonata species (collectively): Calopteryx splendens (HARRIS, 1782), Lestes sponsa**, Chalcolestes viridis (VANDER LINDEN, 1825)*, Sympecma fusca*, Ischnura elegans**, Enallagma cyathigerum (CHARPENTIER, 1840)**, Coenagrion puella**, Erythromma najas (HANSEMANN, 1823)*, E. viridulum (CHARPENTIER, 1840)**, Aeshna

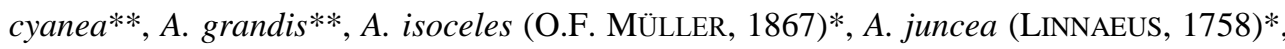
A. mixta**, Anax imperator**, Cordulia aenea (LiNNAEUS, 1758)**, Orthetrum cancellatum**, Crocothemis erythraea (BRULLÉ, 1832)*, Sympetrum depressiusculum (SÉLYS, 1841)*, S. meridionale (SÉLYS, 1841)*, S. sanguineum**, S. vulgatum (LINNAEUS, $1758)^{* *}$.

\section{DISCUSSION}

\section{Distribution of Aeshna viridis in Central and East-Central Europe}

Aeshna viridis inhabits a wide spectrum of stagnant and slowly flowing waters, but its occurrence is limited by its obligatory relationship with Stratiotes aloides (PETERS 1987). The leaves of this plant are where the eggs are laid, and the larvae live among its leaves. The presence of $S$. aloides is crucial for their survival: it protects them from attack by fish and larvae of other dragonfly species (RANTALA et al. 2004, SUUTARI et al. 2004). Nevertheless, the distribution area of A. viridis in Europe (DIJKSTRA \& LEWINGTON 2014) is not wholly sympatric with that of $S$. aloides, which extends farther to the south and west (HULTÉN \& FRIES 1986). This suggests the importance of other environmental factors, possibly climate conditions. The contiguous part of the distribution area of A. viridis ends in Poland. Farther west it occurs only in central and northern Germany and in the Netherlands but its occurrence is insular and scattered (DIJKSTRA et al. 2002, BÖNSEL et al. 2010). In the Czech Republic and Slovakia, which share a border with Poland in the south, A. viridis does not occur at all (DOLNÝ et al. 2007, ŠACHA 2012). In contrast, there are single sites and small small islands of occurrence in Hungary, Croatia and Austria (ST. QUENTIN 1944, RAAB et al. 2007, vAN TOL et al. 2013).

Historically, the border of the distribution area of A. viridis ran through southern Poland. It was determined by the following sites: Lubaczów $\left(50^{\circ} 09^{\prime} \mathrm{N}, 23^{\circ} 07^{\prime} \mathrm{E}\right)$ (DZiĘDZIELEWICZ 1902), Chorzów (50¹7’N, 1857’E) (SCHOLZ 1909) and Wrocław $\left(51^{\circ} 06^{\prime} \mathrm{N}, 17^{\circ} 02^{\prime} \mathrm{E}\right)$ (WOLF 1939). Since those records, A. viridis has not been recorded in south-eastern Poland. In Upper Silesia it was last reported by SAWKIEWICZ \& ŻAK (1966), while in north-western Poland there was only one isolated site in the Silesian-Lusatian Lowland (BORKOWSKI 1999). Therefore, it was concluded that the distribution area of A. viridis had retreated northwards by almost $1^{\circ}$ in the west of the country and by approx. $0.5^{\circ}$ in the east (BERNARD et al. 2009). In Ukraine the situation was similar: in the west A. viridis had not been recorded for almost 100 years (GORB et al. 2000). Within the last 
few decades, it was observed only in the Kiev Oblast (northern Ukraine) (GoRB et al. 2000, KONOVALOVA \& BUï 2012).

In the light of this data, the sites we found are especially interesting. They lie well beyond the contemporary distribution area of A. viridis, on the border of the historical distribution area (Trestno) or just beyond it (Krasiczyn, Bolestraszyce) (Fig. 1). They demonstrate that $A$. viridis, at least locally, still inhabits areas that were thought to have been abandoned (BERNARD et al. 2009).

Changes in the distribution areas of many dragonflies are currently being discussed against the background of global warming; this is very often a reasonable approach. One can distinguish the species that are benefitting from this phenomenon and those that are losing out. The "winners" are thermophilous species, representing a broadly defined Mediterranean zoogeographical element, while the "losers" are cryophilous Siberian species (e.g. OTt 2001, FlenNNer \& SAHLÉn 2008, BERnARD et al. 2009, CONZE et al. 2010, DE KNIJF et al. 2011). The regress of Siberian A. viridis on the southern edge of its distribution area in east-central Europe, including Poland, would appear to fit this pattern. However, our data casts a different light on this. Not every change in distribution area, even of species potentially sensitive to climatic conditions, has to be directly attributed to warming. Changes in habitats, such as the temporary drying out of previously permanent water bodies or modifications in their management, are also important (BERNARD et al. 2002, ClAusNitZER 2003, OTT 2007). This can be related to global warming as warmer water bodies dry out more quickly, but this relationship is not obligatory or may be only partial: drained areas, even ignoring climate change, are more susceptible to drying out. With the exception of the lake districts, Polish data indicates that $A$. viridis is frequently associated with the valleys of large rivers (DZIĘDZIELEWICZ 1902, BUCZYŃSKI 1994, 2007, 2012, JÖDICKE 1999, TOŃCZYK 2007, KovÁCS et al. 2009, data in this paper). The transformation of river valleys and river regulation (KUCHARCZYK 1999) are probably responsible for the partial destruction of potential habitats. The effects of the latter could also be accelerated by climate warming, rendering many water bodies astatic. Without a doubt, it is quite unfavourable for $A$. viridis, whose life cycle in Poland lasts two years (MüNCHBERG 1930) and it is not adapted to drying out. Water bodies colonised by A. viridis are especially vulnerable to such changes because Stratiotes aloides usually grows in shallow eutrophic waters in the late stages of succession (REFOLS 1991, SMOLDERS et al. 1996, CHOVANEC \& WARINGER 2001). This was confirmed by our search for $S$. aloides habitats near Wrocław. The present rediscovery of A. viridis on the edge of its distribution area indicates that the main reason for its disappearance lies in the indirect impact of climate changes coupled with habitat changes possibly caused by human activities. However, if suitable habitats with Stratiotes aloides are preserved, A. viridis can still exist there. The populations at Bolestraszyce and above all at Krasiczyn are small, so it 
is difficult to assess their prospects of survival at those sites, but the population at Trestno seems to be large and most likely stable.

\section{Implication for management}

An interesting aspect of the data presented in this paper is the artificial character of these Aeshna viridis sites. This shows that effective conservation of this dragonfly is feasible by the creation of new water bodies and the introduction of Stratiotes aloides. This is especially evident at Bolestraszyce, where the plant was artificially introduced in the second half of the last decade (ANTONIEWSKA \& CZERNICKI pers. comm.). According to MAUERSBERGER et al. (2005), $5 \mathrm{~m}^{2}$ is the minimum surface area of Stratiotes aloides enabling A. viridis to survive, but optimal patches are at least $50 \mathrm{~m}^{2}$ in area. The size of $S$. aloides patches was also reported as significant by SUHONEN et al. (2013); our observations confirm this. The greatest numbers of A. viridis were found at Trestno, where there are large patches of S. aloides. In the Bolestraszyce ponds, where the patches are ca 50-100 $\mathrm{m}^{2}$ in area, only a few individuals were observed. The population at Krasiczyn was the smallest, where, at best, only single $S$. aloides plants exist as an admixture to the beds of Phragmites australis.

It is strongly recommended to initiate a programme evaluating the known sites of Stratiotes aloides (preferably in cooperation with botanists), coupled with an extensive search for Aeshna viridis at such sites and followed by the implementation of appropriate conservation measures. Certainly, only a few of the existing A. viridis sites have been found so far. Such a study should focus primarily on river valleys, large natural bodies of stagnant waters (especially oxbow lakes) and anthropogenic water bodies (fish ponds, flooded gravel, clay and sand excavations). All these activities could contribute to the body of knowledge about the dragonflies in the whole of southern Poland, where vast areas have still been insufficiently explored. This is particularly true as far as Lower Silesia is concerned, where existing data are largely historical (BERNARD et al. 2009). With respect to A. viridis this should lead to a better explanation of its actual situation and, where necessary, be a prelude to a more rational conservation approach.

\section{ACKNOWLEDGEMENTS}

The authors express their gratitude to Ewa ANTONIEWSKA and Mariusz CZERNICKI from the Arboretum and the Physiography Department at Bolestraszyce for information about the occurrence of Stratiotes aloides in the arboretum and adjacent areas. We are very grateful to Zygmunt DAJDOK from the Institute of Environmental Biology of the University of Wrocław and Jarosław PROĆKów from the Institute of Biology of the Wrocław University 
of Environmental and Life Sciences for the valuable data on the occurrence of S. aloides in Lower Silesia and for their comprehensive assistance in the identification of plants. We also thank the two anonymous reviewers for their invaluable comments on the first version of the manuscript.

Part of the research in south and south-eastern Poland was carried out within the framework of research project No. 2 P04C 129 29, financed by the Ministry of Science and Higher Education of the Republic of Poland.

\section{REFERENCES}

BERnARD R., BUCZYŃSKi P., ToŃCZYK G. 2002. Present state, threats and conservation of dragonflies (Odonata) in Poland. Nature Conservation 59(2): 53-71.

Bernard R., BuCZyŃSKi P., TOŃCZYK G., WENDZONKA J. 2009. A distribution atlas of dragonflies (Odonata) in Poland. Bogucki Wydawnictwo Naukowe, Poznań.

Bönsel A., MAUERSBerger R., WACHLIN V. 2010. Steckbriefe der in Mecklenburg Vorpommern vorkommenden Arten der Anhänge II und IV der FFH Richtlinie. Aeshna viridis (EvERSMAnN, 1836), Grüne Mosaikjungfer. Landesamt für Umwelt, Naturschutz und Geologie des Landes Mecklenburg-Vorpommern, Güstrow. Internet: http://www.lung.mv-regierung.de/dateien/ffh_ asb_aeshna_viridis.pdf

BORKOWSKI A. 1999. Dragonflies (Odonata) of the former province of Jelenia Gora with the notes to the current state of research, threats and conservation needs. Przyroda Sudetów Zachodnich 2: 37-56. (in Polish)

BUCZYŃSKi P. 1994. New records of rare dragonflies (Odonata) from eastern Poland. Wiadomości Entomologiczne 13(2): 129-130. (in Polish)

BuCZYŃSKi P. 2007. Dragonflies (Odonata) of the valley of the River Bug between Gołębie and Włodawa. Nowy Pamiętnik Fizjograficzny 5(1-2): 3-26. (in Polish)

BuCZYŃSKi P. 2012. Dragonflies (Odonata) of the left-bank Bug River valley between Włodawa and Kodeń (middle-eastern Poland). Acta Biologica 19: 47-69.

ChOvanec A., WARINGER J. 2001. Ecological integrity of river/floodplain-systems - assessment by dragonfly surveys. Regulated Rivers: Research \& Management 17(4-5): 493-507.

Clausnitzer H.-J. 2003. Ausbreitung von Ceriagrion tenellum und Orthetrum coerulescens in der Südheide. Pedemontanum Sonderh. GdO-Tagung 2003: 13-14.

Conze K.-J., Grönhagen N., Lohr M., Menke N. 2010. Trends in occurrence of thermophilous dragonfly species in North Rhine-Westphalia (NRW). BioRisk 5: 31-45.

De Knijf G., Flenker U., Vanappelghem C., Manci C.O., Kalkman V., Demolder H. 2011. The status of two boreo-alpine species, Somatochlora alpestris and S. arctica, in Romania and their vulnerability to the impact of climate change (Odonata: Corduliidae). International Journal of Odonatology 14(2): 111-126.

Dijkstra K.-D.B. (ed.), Lewington R. 2014. Libellen Europas. Der Bestimmungsführer. Haupt, Bern. 
Dijkstra K.-D.B., Kalkman V.J., Ketelaar R., VAn DeR Weide M.J.T. 2002. Dragonflies of the Netherlands: Odonata. Nationaal Natuurhistorisch Museum Naturalis, KNNV Uitgeverij, European Invertebrate Survey Nederland, Leiden - Utrecht - Leiden. (in Dutch)

Dolný A., Bárta D., Waldhauser M., Holuša O., Hanel L. 2007. Dragonflies of the Czech Republic. Ecology, Conservation and Distribution. Český svaz ochránců př́írody, Vlašim. (in Czech)

DZIĘDZIELEwicz J. 1902. Dragonflies of Galicia and adjacent Polish countries. Muzeum Dzieduszyckich, Lwów. (in Polish and Latin)

FLENNER I., SAHLÉN G. 2008. Dragonfly community re-organisation in boreal forest lakes: rapid species turnover driven by climate change? Insect Conservation and Diversity 1(3): 169-179.

GN [Guardians of NATURe] 2014. PLH020017 Alluvial alder ashes in the Valley of the River Odra. Internet: http://www.obszary.natura2000.pl/index.php?dzial=2\&kat=9\&art=21 (in Polish)

Gorb S.N., PAwlJuk R.S., SpuRIS Z.D. 2000. Odonata of Ukraine: a faunistic overview. Vestnik Zoologii Suppl. 15: 1-154. (in Ukrainian)

HÜBER D. 1924. Königreich Galizien und Lodomerien herausgegeben im Jahre 1790 von Liesganig. Nach den vorzüglichsten neuern Hülfsquellen. General Quartiermeister Stabe, Wien.

HULTÉN E., FRIES M. 1986. Atlas of North European vascular plants: north of the tropic of cancer. 1: introduction taxonomic index to the maps 1-996: Maps 1-996. Koeltz, Königstein.

JöDICKE R. 1999. Libellenbeobachtungen in Podlasie, Nordost-Polen. Libellula 18(1/2): 31-48.

KONDRACKI J. 2000. Regional geography of Poland. PWN, Warszawa. (in Polish)

Konovalova Ya.P., Buİ D.D. 2012. List of dragonfly species (Insecta: Odonata) from PereyaslavKhmelnitsky District of Kyiv Region. The Kharkov Entomological Society Gazette 20(1): 15-18. (in Ukrainian)

Kovács T., Ambrus A., Olajos O., SziláGi G. 2009. Records of Ephemeroptera and Odonata from the Biebrza National Park, Poland. Folia Historico Naturalia Musei Matraensis 33: 87-96.

KUCHARCZYK M. (ed.) 1999. Problems of the protection and re-naturalisation of the valleys of big European rivers. Wydawnictwo UMCS, Lublin. (in Polish)

MÜNCHBERG P. 1930. Zur Biologie der Odonatengenera Brachytron Evans und Aeschna FBR. Zeitschrift für Morphologie und Ökologie der Tiere 20(1): 172-232.

Отт J. 2001. Expansion of Mediterranean species in Germany and Europe - consequences of climatic changes [in:] G.R. WALTER, C.A. BURGA, P.J. EDwARDS (eds). "Fingerprints" of Climate Change. Adapted Behaviour and Shifting Species Ranges. Kluwer Academic / Plenum Publishers, New York - Boston - Dordrecht - London - Moscow: 89-111.

Oтт J. 2007. Hat die Klimaänderung eine Auswirkung auf das Netz Natura 2000? - Erste Ergebnisse aus Untersuchungen an Libellenzönosen dystropher Gewässer im Biosphärenreservat Pfälzerwald. Naturschutz und Biologische Vielfalt 46: 65-90.

Ott J., PiPer W. 1998. Rote Liste der Libellen (Odonata). [in]: M. Binot, R. Bless, P. Boye, H. GruTtke, P. Pretscher (eds). Rote Liste gefährdeter Tiere Deutschlands. Schriftenreihe für Landschaftspflege und Naturschutz 55: 260-261.

Peters G. 1987. Die Neue Brehm-Bücherei Bd. 585. Die Edelibellen Europas, Aeshnidae. Ziemsen, Wittenberg Lutherstadt. 
RaAb R., Chovanec A., Pennenrstorfer J. 2007. Libellen Österreichs. Springer, Wien - New York.

Rantala M.J., Ilmonen J., Koskimäki J., Suhonen J., Tynkkynen K. 2004. The macrophyte, Stratiotes aloides, protects larvae of dragonfly Aeshna viridis against fish predation. Aquatic Ecology 38(1): 77-82.

ROELOFS J.G.M. 1991. Inlet of alkaline river water into peaty lowlands: effects on water quality and Stratiotes aloides L. stands. Aquatic Botany 39(3-4): 267-293.

ŠACHA D. 2012. Dragonflies of the Slovak Republic. Internet: http://www.vazky.sk/ (in Slovak)

SAwKIEWICZ L., ŻAK M. 1966. Dragonflies (Odonata) of Silesia. Rocznik Muzeum Górnośląskiego w Bytomiu (Przyroda) 3: 73-132. (in Polish)

Scholz E.J.R. 1908. Die schlesischen Odonaten. Zeitschrift für Wissenschaftliche Insektenbiologie, 4(11,12): 417-420, 457-462.

Smolders A.J.P., Roelofs J.G.M., Den Hartog C. 1996. Possible causes for the decline of the water soldier (Stratiotes aloides L.) in the Netherlands. Archiv für Hydrobiologie 136(3): $327-342$.

ST. Quentin D. 1944. Die Libellenfauna Dalmatiens. Verhandlungen der Zoologisch-Botanischen Gesellschaft in Wien 90/91: 66-76.

Suhonen J., SuUtari E., Kaunisto K.M., Krams I. 2013. Patch area of macrophyte Stratiotes aloides as a critical resource for declining dragonfly Aeshna viridis. Journal of Insect Conservation 17(2): 393-398.

Suutari E., Rantala M.J., Salmela J., Suhonen J. 2004. Intraguild predation and interference competition on the endangered dragonfly Aeshna viridis. Oecologia 140(1): 135-139.

SzTwIERTNIA D. 2014. Alluvial alder ashes in the Valley of the River Odra. Internet: http://natura 2000-dolnyslask.pl/menuspa/97-gradyodrzanskie.html (in Polish)

Świerkosz K., DAJdok Z., MALKIEwicz A. 2012a. Alluvial alder ashes in the Valley of the River Odra. [in:] K. Świerkosz, H. Liberacka, M. ŁysiaK, K. Zając. Natura 2000 sites in the Lower Silesia. Regionalna Dyrekcja Ochrony Środowiska we Wrocławiu, Wrocław, 128-130. (in Polish)

Świerkosz K., LiBeracka H., ŁysiaK M., ZAJĄC K. 2012b. Natura 2000 sites in the Lower Silesia. Regionalna Dyrekcja Ochrony Środowiska we Wrocławiu, Wrocław. (in Polish)

TermaAt T., Kalkman V.J. 2012. Odonata Red List Report 2011 using Dutch and IUCN criteria. Brachytron 14(2): 75-186. (in Dutch)

ToŃCZYK G. 2007. Moreover than dragonfly impressions from field studies at northern Masovia. Odonatrix 3(1): 19-21. (in Polish)

van Tol J., Bernard R., Kalkman V., Khrokalo L., Marinov M., Pelt G.J., Skvortsov V. 2013. Aeshna viridis. [in:] Y.S.D.M. de JoNG (ed.). Fauna Europaea version 2.6. Internet: http://www. faunaeur.org

WOLF W. 1939. Schlesische Libellen. Zeitschrift für Entomologie 18(3): 12.

Received: 28 January 2015

Accepted: 16 February 2015 